\title{
Non-Tariff Measures Affecting Agricultural Trade in SADC
}

\section{Kalaba}

Department of Agricultural Economics, Extension and Rural Development, University of Pretoria

Mmatlou.kalaba@up.ac.za

\section{J. Kirsten}

Department of Africultural Economics, Extension and Rural Development, University of Pretoria johann.kirsten@up.ac.za

T. Sacolo

Department of Agricultural Economics, Extension and Rural Development, University of Pretoria sacolo.sacolo72@gmail.com

\begin{abstract}
The establishment of the World Trade Organisation in 1995 and subsequent proliferation of the regional and bilateral trade agreements resulted in the decline of global tariffs. However, other trade and regulatory measures have increased and thus restricted potential trade to some extend. These measures, non-tariff measures (NTMs) have also affected intra-SADC trade as there was no evidence of growth in the trade that needed to accompany the decline in tariffs. The extent of the impact of NTMs on SADC trade is still not fully understood due lack of such data, which effectively affected the quality of research in this area. In this paper data on NTM related to SADC agricultural products for ten countries were compiled to shed some light on these measures as well as to make them transparent. The results confirm that these countries have increased their use of NTMs of the period. As a result, on average one product is subjected to 17 NTMs in 2010. SACU is the leader in the use of NTMs, while Malawi had the least incidences of NTMs. Most of The NTMs are applied on fruits, meat, dairy, vegetables and cereal products. The use of sanitary and phyto-sanitary measures (SPS) and export measures were increasing faster than other categories. Finally, there is an indication that NTMs are used as substitutes for the declining tariffs. NTMs are trade restricting, and if they are not addressed they will continue to reverse the gains of SADC free trade area as well as other initiatives of trade liberalisation.
\end{abstract}

Key words: non-tariff measures, agricultural products, SADC trade JEL classification: F150 and Q170 


\section{Introduction}

Global tariff protection has been negotiated downwards through many rounds of World Trade Organisation (WTO) negotiations, regional integration initiatives and bilateral agreements (WTO, 2008). But other policies have increasingly provided restrictions to international trade. These policy measures are generally referred to as non-tariff measures (NTMs). NTMs are defined as any measures other than tariffs that distort trade. They pose a different and difficult problem, relative to tariffs. Similarly to tariffs, NTMs restrict or distort trade, affect domestic prices and impact welfare. At the same time these measures used for necessary and legitimate policy goals, such as food safety and to protect animal health. However, unlike tariffs, some NTMs are unquantifiable, sometimes unobservable until they are applied and many of them are usually not transparent (Martinez, Mora and Signoret, 2009).

The challenges relating to NTMs are not necessarily a new phenomenon. While the policy challenge has remained the same as in the early General Agreements on Tariffs and Trade (GATT), the specific issues, debates and solutions have evolved over time (WTO, 2012). In the past NTMs were often driven, or influenced in terms of design, by producer interests. The focus was on national measures, and ensuring that the WTO principles of non-discrimination and transparency are upheld. This was done while avoiding protectionism.

Recently NTMs reflect a greater diversity in public policy concerns, including consumer interests (UNCTAD, 2012). There is a growing focus on transnational measures as well as encouraging regulatory cooperation, mutual recognition agreements and the international harmonization of standards. Within these challenges, there are still data problems on NTMs are highly fragmented as they affect various aspects of the product flow, can be applied for unlimited number of reasons (for example, economical, health, trade, religious, political, and many others); and unlike tariffs, they can be introduced by any agency or institution. Then there are problems that are related to the application of NTMs due to administrators that are not trained necessarily to deal with such issues (Cadot and Malouche, 2012). This increases the opaqueness of NTMs and escalates their effects.

These challenges affect developed and developing countries differently, and differ from one trade arrangement to another or from country to country. It is well-known that developing countries are affected more by NTMs due to lack of resources required to implement their own measures or to comply with requirements elsewhere (Cadot and Gourdon, 2012). This paper presents the NTMs applied by Southern African Development Community (SADC) countries on agricultural products. The same NTMs applied by the SADC countries are faced by the member states while trading with one another.

The SADC process towards trade liberalization started in 1996 with the signing of the protocol on trade. Article six of SADC trade protocol indicates that NTMS will be removed over the implementation period (SADC, 2004). Trade liberalisation will be considered attained when $85 \%$ of trade within the SADC region takes place free of customs duties and a free trade area (FTA) has been established. The protocol was implemented from the year 
2000 when it was ratified by eleven members ${ }^{1}$ by following the WTO's special differential treatment (SDT) approach. This differentiation was applied on both products and members. Members were divided into developed countries (Southern African Customs Union (SACU) consisting of Botswana, Lesotho, Namibia, South Africa and Swaziland), developing (Mauritius and Zimbabwe) and least developing (Malawi, Mozambique, Tanzania and Zambia). Developed countries were required to front-load the tariff phase down and to reduce most its tariffs within five years. Mauritius and Zimbabwe had up to year six and seven to reduce most of the tariffs, while the least developed countries had up to year eight to reduce up to $85 \%$ of its tariffs to zero.

Product differentiation involved dividing products into three groups. Group A were products which were to be bound to zero at the beginning of the implementation period. Group B included products which were to be phased down to zero trade over a period of eight years. Finally, Group C constituted exclusion list of products from the tariff phase down. Most countries decided to protect agricultural sector by including majority of the sector's products on this exclusion list.

The agriculture sector has a major social and economic importance in the SADC region. The sector contributes between 3\% and 27\% of GDP and approximately $13 \%$ of overall export earnings (SADC Secretariat, 2012). About 70\% of the region's population depends on agriculture for food, income and employment. Hence the performance of this sector has a strong influence on food security, economic growth and social stability in the region. The way the subject of NTMs is addressed in the region will be of high importance in these sectoral contributions and goals are achieved.

The effects of NTMs on trade are ambiguous (UNCTAD, 2010). For example, compliance with regulatory measures may lead to higher costs, which will eventually be passed through to consumers. As a result the high costs may restrict market access for exporters. These may also provide protection to the domestic producers of the same good. However, higher regulatory requirements may raise consumer confidence in the quality of imported goods. As a result, such confidence may lead to high demand for the same imported good.

The paper presents a descriptive compilation of the NTMs affecting agricultural products within SADC countries from year 2000 to 2010. The paper uses the classification of the Multi-Agency Support Team (MAST) to categorise NTMs in the region (UNCTAD, 2010). The first objective of the paper is to provide the first effort in collecting NTM data that will shed some light on the prevalence and pervasiveness of NTMs. Secondly, to provide transparency in this area of trade policy. This is important for, governments and policy makers to understand the importance of addressing NTMs as part of domestic competitiveness and regulatory reforms.

\footnotetext{
${ }^{1}$ SADC members that ratified the trade protocol are Botswana, Lesotho, Malawi, Mauritius, Mozambique, Namibia, South Africa, Swaziland, Tanzania, Zambia and Zimbabwe.
} 
The rest of the paper is structured as follows: the next section gives the brief review of intraSADC trade over the past decade. It is then followed by definition on NTMs. Section four reviews the classifications of NTMs that are predominant in agricultural trade. Section five looks at the NTMs in SADC which have been compiles by the authors. They are discussed in terms of the method of compilation and sources, country applying NTMs, products affected by NTMS as well as types of NTMs used. The final section provides concluding remarks and further work that needs to be done.

\section{Share of SADC trade}

SADC began implementing the protocol on trade in the latter half of the year 2000 (SADC Secretariat, 2004). This was after the protocol was signed in 1996. The significance of the implementation was the reduction of customs tariffs. The formula for tariff reduction was agreed upon, prior to the implementation of the protocol. In that developed countries of SACU reduced majority of the tariffs in the early years and complete within five years. The developing countries, Mauritius and Zimbabwe were to reduce at a medium pace. Countries which were classified as least developed were allowed more time of up to eight years to implement the protocol on trade ${ }^{2}$.

This was the first step towards trade liberalisation in the region. It was intended to result in more trade between member states. The overall aim was to improve trade performance between the member states relative to non-SADC members. The SADC trade performance is assessed using two basic measures of trade performance.

First, a share of intra-SADC agriculture imports over the years is compared with agriculture imports from non SADC members. Definition of agricultural products in this paper follows the WTO product coverage in terms of the harmonised systems (HS)( WTO, 1995). HS 1 through to 24, excluding fisheries (HS 3). Other products included are raw hides and skin, leather and furskin products (HS 41-43), and finally wool, cotton and textile fibre products (HS 51 -53). It is expected that intra-SADC imports will be starting at low base, hence the initiative to improve the situation through the tariff reduction. This is mainly because tariffs constitute cost of trade, and thus any reduction of this cost should lead to improvement in trade. If intra-SADC trade is improving, then over the period intra-SADC imports should be getting close to non-SADC imports. The long term objective is to surpass it.

Then, an evaluation of this intra-SADC trade objective is done using growth rate of intraSADC imports relative to that of Non SADC members. Imports refer to those of agricultural products as explained earlier. The assessment uses nominal import values from 2000 to 2010. Furthermore, trade is broken down into two halves to observe whether there was any change

\footnotetext{
${ }^{2}$ Other SADC members were not part of the trade protocol or had not acceded to the regional bloc. Angola and the DRC had not ratified the protocol on trade at this stage, while Seychelles and Madagascar acceded later.
} 
over the eleven year period. If intra-SADC trade was improving, then the growth of intraSADC imports should be higher than that of non SADC imports. Table 1 shows SADC trade in value as well as growth rates over the eleven year period.

Table 1: Comparison of Intra-SADC and non SADC agricultural imports (US\$ and growth rates)

\begin{tabular}{|c|c|c|c|c|}
\hline & \multicolumn{2}{|c|}{ US \$ billion } & \multicolumn{2}{|c|}{ Growth (\%) } \\
\hline Year & intra-SADC & Non SADC & intra-SADC & Non SADC \\
\hline 2000 & 1.39 & 2.79 & - & - \\
\hline 2001 & 1.48 & 2.68 & $6 \%$ & $-4 \%$ \\
\hline 2002 & 2.08 & 3.03 & $41 \%$ & $13 \%$ \\
\hline 2003 & 2.21 & 3.84 & $7 \%$ & $27 \%$ \\
\hline 2004 & 3.00 & 4.95 & $35 \%$ & $29 \%$ \\
\hline 2005 & 2.46 & 4.97 & $-18 \%$ & $0 \%$ \\
\hline 2006 & 2.37 & 6.11 & $-4 \%$ & $23 \%$ \\
\hline 2007 & 2.74 & 7.91 & $16 \%$ & $29 \%$ \\
\hline 2008 & 3.16 & 8.69 & $15 \%$ & $10 \%$ \\
\hline 2009 & 3.79 & 7.64 & $20 \%$ & $-12 \%$ \\
\hline 2010 & 3.68 & 8.74 & $-3 \%$ & $14 \%$ \\
\hline Average 2000-10 & 2.58 & 5.58 & $11 \%$ & $13 \%$ \\
\hline Average 2000- 04 & 2.03 & 3.46 & $22 \%$ & $13 \%$ \\
\hline Average 2005- 10 & 3.03 & 7.34 & $4 \%$ & $11 \%$ \\
\hline
\end{tabular}

Source: Calculations from UN COMTRADE Database, 2012

The results of growth assessment are summarised at the bottom part of Table 1 . The average value of intra-SADC imports per year over the whole period was US\$ $2.58 \mathrm{bn}$, and while imports from non SADC were more than double intra-SADC value (US\$ 5.58bn). On average, non-SADC imports were growing at a faster pace than intra-SADC imports, that is an average of $13 \%$ per annum compared to $11 \%$ of intra-SADC imports. When the period was split into two halves, intra-SADC imports grew faster between 2000 and 2004 (22\% per annum) compared to no SADC imports (13\% per annum). This is over the period when only SACU reduced its tariffs as a result of frontloading its phase down process. But in the latter years, when SADC was actually reducing more tariffs and getting closer to a free trade area, the growth was at a much slower pace of $4 \%$ per annum. Therefore, SADC countries are still importing relatively more from non SADC members despite the incentives of low tariffs within the region. Then overall, the performance of intra- SADC trade was low when compared to non SADC trade.

The last method of assessment compares tariff reduction of agricultural products with intraSADC import share. The assessment uses the relationship between tariffs trade to evaluate performance. Since tariffs are trade costs, therefore any reduction of costs should lead to trade improvement. So the performance will be considered to be improving if over this period, the share of intra-SADC imports is growing as a result of reduction of trade costs. From 1 below shows that agricultural tariffs (trade costs) have declined from about an 
average of $15 \%$ in 2000 to less than 5\% in 2010. The tariffs used were average simple tariffs, as they were to be phase down as per trade protocol implementation. However, the share of intra-SADC imports, which was expected to be increasing, has actually declined for most of the middle period. Initially it rose from about 33\% to $40 \%$ in 2002, but then started to decline. It started picking up around 2008, but it is still at the levels of more than ten years ago. This is again another indication that SADC trade performance has not improved, despite protection in the form of tariffs being reduced.

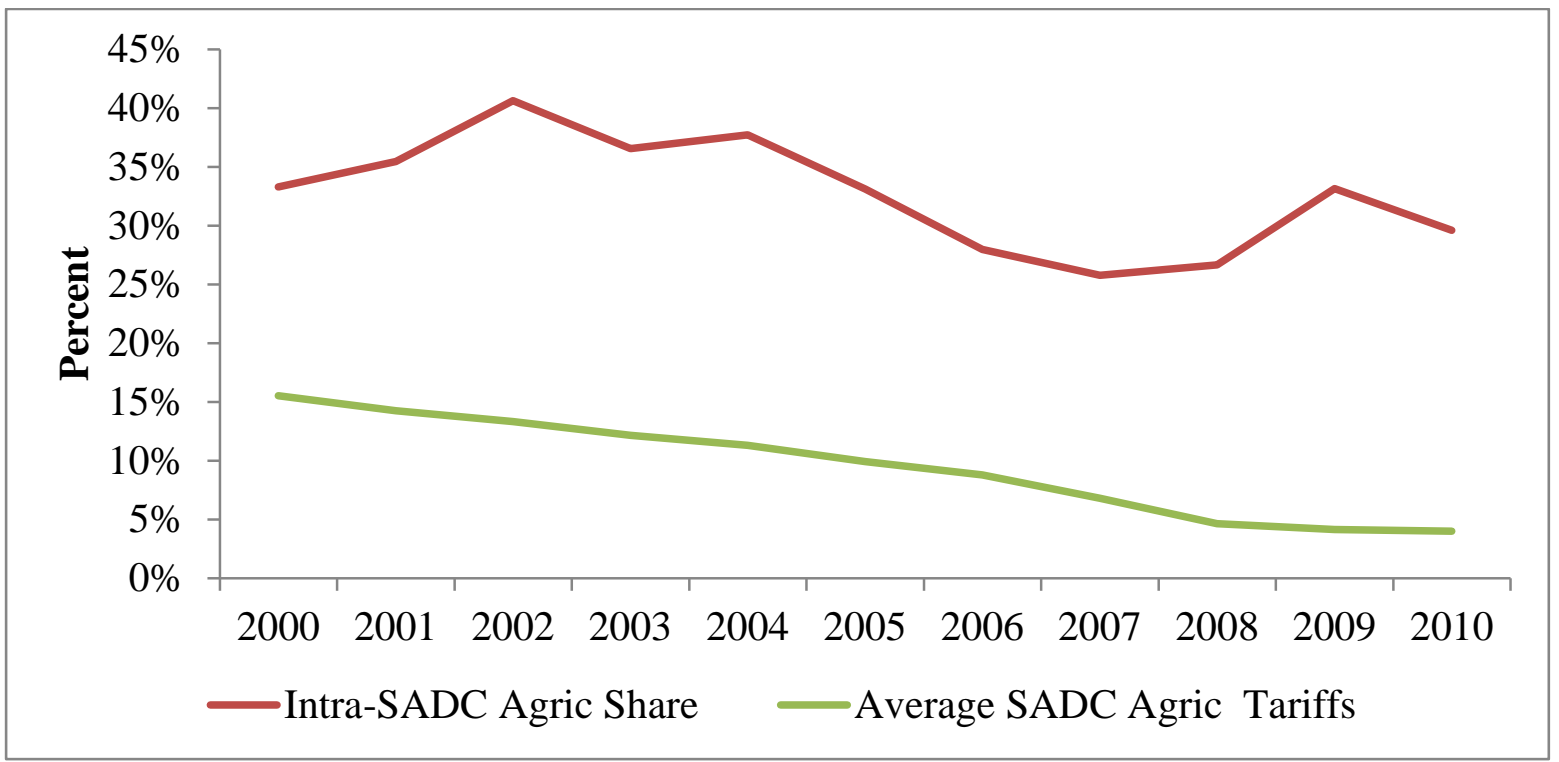

Figure 1: Intra-SADC import share of agriculture products and agricultural tariffs Source: Calculated from UNCOMTRADE Database and SADC Secretariat

The above results SADC trade performance has not improved in the past decade. The three measures which were used to assess this performance showed consistent results of lower than expected trade performance. While there could be several reasons to explain this poor performance, some of those have to do with the NTMs. World Bank (2012) identify some of the reasons for low intra-regional trade on the continent as high transaction costs, which drive trade costs up and subsequently limit trade. In this paper we are not testing whether NTMs are the causes of such low trade performance or not, but explain their use within SADC. In the next section we discuss various definitions of NTMs.

\section{Definition of NTMs and Classifications}

NTMs are generally understood to refer to any measure that causes trade distortion, as long as it is not a tariff. Therefore the term is a residual category of measures and actions that restrict to various degrees and different ways the market access of goods (WTO, 2012). Thus, an NTM can be defined broadly as any measure that causes a trade distortion other than the tariffs (Carrere and De Melo, 2009). A distortion in trade exists when the domestic price differs from a border price. These include export measures as well, such as bans and export subsidies. A distortion can also be introduced deliberately by governments such a quantitative 
restriction. It may also be the outcome of unintended objective such as a regulatory action like sanitary measure.

The functional definition of NTMs deals basically with economic effects. Baldwin (1970) describes them as "non-tariff distortions", and that refers to any measures, public or private that cause internationally traded goods and services, or resources devoted to the production, of goods and services to be allocated in such a way that potential real world income is reduced. Lloyd (1996) uses the same concept in the law of one price in the regional single market. He argues that NTMs are included together with other restrictions such as taxes which effectively prevent the law of one price from being effectively implemented.

The operational definition of NTMs deals with the identification of the measures and provides the taxonomy of NTMs (UNCTAD, 2012). This definition focuses on items that are included and excluded from the list of NTMs. Such a list may never be concluded because theoretically any measure can have the price-raising, trade-reducing, welfare-reducing and other economic effects. The approach of drawing such an inventory is very important as the list can be harmonised with an analytical perspective. Therefore the analysis of the economic effects should depend on such an inventory of measures.

By definition, NTMs cover a broad array of regulations affecting traded products. The term "NTM" designates a vast range of heterogeneous regulatory instruments (Cardot and Gourdon, 2012). Within all the trade distortions which are applicable to trade, some are justifiable while others are not. When a distortion is introduced explicitly to protect domestic industry by restricting import demand, then it is classified as non-tariff barrier (NTB). NTBs may include internal measures such as production subsidy and many other administrative measures.

The key distinguishing feature of NTBs from NTMs is that NTBs have protectionist intent. Some examples of NTBs include quotas, tariff-rate quotas, licensing regimes, import and export bans and price bands. On the other hand, NTMs include all measures that distort trade. In many cases it is really difficult to separate NTMs from NTBs, as measures which may have introduced to protect consumers from a known or perceived threat, may remain after the threat has been removed.

Regarding classification of NTM information, there is a problem with data accessibility, i.e., even in cases when data was available, it was not always available at the same place. NTM data are usually scattered and therefore not readily accessible. The United Nations Commodity Trade and Development (UNCTAD) and the Trade Analysis Information Systems (Trains) developed one of the internationally accessible databases of NTMs (Bacchetta et al, 2012). The database was developed in 1988 and has coverage of about 100 countries. The classification uses Trade Control Measures Coding System (TCMCS). It is divided into six main categories, namely: price control measures, finance measures, 
automatic licensing, quantity control measures, monopolistic competition and technical measures; production and export measures; and technical barriers.

The classification had two main weaknesses. The first one is that it excludes measures applied to exports and production. Following the functional definition of NTMs, the two measures should be part of the classification. Measures that are supportive of export and production distort trade and therefore should have been included in the classification. Secondly, by early 2000's the database was outdated (Carrere and De Melo, 2009). The database was not maintained and updated regularly.

The classification was adjusted to include the intent to indicate the impact of the measures (Wolfe, 2003). Five different categories were identified, and this time covering restrictions as well as subsidies. The categories were;

- Subsidies;

- measures dealing with volume of imports;

- measures dealing with the price of imported goods;

- monitoring measures (include price and volume investigations) and

- Surveillance measures.

Although this classification was an improvement from the previous ones, it still included some arbitrariness and overlapping attributes in several categories. For example, most measures have price and quantity effects.

The shortcomings of the UNCTAD-TRAINS database (described above) resulted in UNCTAD considering other options to classify and capture NTMs. In 2006 UNCTAD established a called Group of Eminent Persons on Non-Tariff Barriers (GNTB). The terms of reference for the GNTB were broad with regards to the NTMs and existing database. But the significant one was for the team to "make recommendations on the issues of definition, classification and quantification of NTMs". The classification of NTMs that was produced is taxonomy of all those measures considered relevant in today's situation in international trade (UNCTAD, 2012a). It is based on the UNCTAD Coding System and was developed by several international organizations forming what was called the MAST group (Multi-Agency Support Team) to support the Group of Eminent Persons on NTBs established by the Secretary General of UNCTAD in 2006.

On the issue of the definition it was clear that there is no commonly agreed definition of NTMs. Eventually the GNTB decided to work with the definition of NTMs as, "policy measures, other than tariffs, that can potentially have economic effect on international trade in goods, services, changing quantities traded, or prices or both". Using this definition they classified NTMs according to a hierarchical tree structure where NTMs are disaggregated into 16 "branches" or chapters. These chapters were denoted by the letters of alphabet, A through to P. Each branch consists of "sub-branch" or 1-digit level, "twigs" or 2-digit level 
and” leaves”, also known as 3-digit level. Table 2 shows the structure of this classification at the "tier" 1 or chapter level.

In broad terms, NTM categories are classified into those that affect imports and exports (Gourdon and Nicita, 2012). The classification does not judge on legitimacy, adequacy, necessity or discrimination of any form of policy intervention used in international trade. It acknowledges existence and is designed to organize information in a database format (UNCTAD, 2012a). So, categories A through to $\mathrm{O}$ are applied to imports. Import measures are further classified into technical and non technical. Categories A and B, SPS and TBT measures are referred to as technical measures. These measures deal with protection of human, animal and plant health, as well as related technical measures and standards. Categories $\mathrm{C}$ to $\mathrm{O}$ are non-technical. Non-technical measures cover a mixture of commandand-control types of measures (price controls, quantitative restrictions and prohibitions) and a disparate set of measures (Cardot and Gourdon, 2012).

Table 2: The MAST Hierarchical NTM Classification

\begin{tabular}{|c|c|c|c|}
\hline Flow & Туре & Code & NTM Description \\
\hline \multirow[b]{2}{*}{ 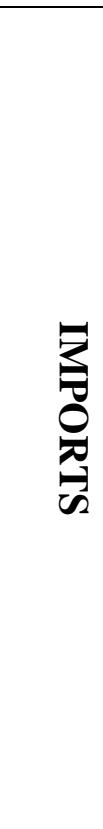 } & Technical & $\begin{array}{l}\text { A } \\
\text { B }\end{array}$ & $\begin{array}{l}\text { Sanitary and phytosanitary measures (SPS) } \\
\text { Technical barriers to trade (TBT) }\end{array}$ \\
\hline & 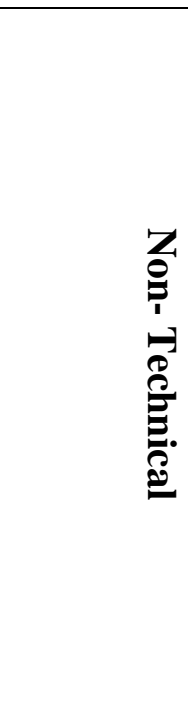 & $\begin{array}{l}\text { C } \\
\text { D } \\
\text { E } \\
\text { F } \\
\text { G } \\
\text { H } \\
\text { I } \\
\text { J } \\
\text { K } \\
\text { L } \\
\text { M } \\
\text { N } \\
\mathbf{O}\end{array}$ & $\begin{array}{l}\text { Pre-shipment inspection and other formalities } \\
\text { Price control measures } \\
\text { Licences, quotas, prohibitions and other quantity control measures } \\
\text { Charges, taxes and other para-tariff measures } \\
\text { Finance measures } \\
\text { Anti-competitive measures } \\
\text { Trade-related investment measures } \\
\text { Distribution restrictions } \\
\text { Restriction on post-sales services } \\
\text { SUBSIDIES (excluding export subsidies under P700) } \\
\text { Government procurement restrictions } \\
\text { Intellectual property } \\
\text { Rules of origin (RoO) }\end{array}$ \\
\hline \multicolumn{2}{|c|}{ EXPORTS } & $\mathbf{P}$ & Export related measures \\
\hline
\end{tabular}

Source: MAST, 2009

Some of the non-technical measures like pre-shipment inspection (category C), are easy to monitor as they are applied irrespective of the product. They are also administrative in nature, as they are part of the daily routine by custom officials. Category $C$ deals with the classification of pre-shipment inspections and customs formalities (UNCTAD, 2012a). These measures can potentially affect all products. Others like taxes and para-tariff measures (category F) are also easier to track as they are often administered in a transparent way (Gourdon and Nicita, 2012). These measures are applied to finance border-management administrations. At times their functions are not always clear (UNCTAD, 2012a). 
Measures $\mathrm{G}$ to $\mathrm{O}$, relates to the process or service (Nicita, 2011). Unlike measures A and B, they are not always imposed on a product. For example, anti-competitive (category $\mathrm{H}$ ) and distribution restrictions $(\mathrm{J})$ can only be observed only when the products are affected by the two processes. These NTMs deal with internal distribution of imported product. Others measures are very difficult to code at the product level like Trade-Related Investment Measures (TRIMS) (I) or intellectual property (N). Subsidies (L) are a particularly difficult case because of the definition that MAST (2009) used for financial contribution ${ }^{3}$.

Subsidies are often to certain companies or sectors and not to others depending on their location, ownership status (ethnic minorities, special groups and so on), or type (SMEs). It is difficult to track all subsidies granted under the numerous schemes typically in place to serve various societal purposes. Even more difficult is to decide when they are sufficiently prevalent to be ascribed to a particular product.

Rules of origin are another category of non-tariff measure. They are required in preferential trade agreements to identify which countries are eligible for reduced or zero tariffs. However, they can be designed in a way which makes them costly to satisfy, which limits the impact of the trade preferences. Rules of origin are also necessary to apply protection measures such as anti-dumping and safeguard measures (UNCTAD, 2009). Thus, including them in the MAST nomenclature gives an appearance of exhaustively but is difficult to operationalize for quantitative work.

Lastly, export measures (category P) are of growing importance, particularly for foodstuffs in times of rising food prices. Gillson (2011) argues that export restrictions in times of high prices contribute to reduce incentives to expand production. This result is shortages which are not beneficial for both over time (because supply does not react) and across space (as producers in surplus regions are banned from arbitraging price differences. So price spikes in deficit regions are not dampened by increased imports. Thus, export restrictions exert negative regional externalities and increase consumer price volatility.

Agricultural trade is largely affected by technical barriers, SPS and TBT measures. SPS are important as by definition, these measures are related to food safety, animal and plant health as well as environment (WTO, 2010a). Agriculture deals more with these issues compared to other sectors of the economy. As a result is expected than these measures will be more prevalent in agriculture than other sectors. Other measures that more applicable to the agricultural sector include export-related measures, i.e., bans and taxes. Subsidies (L) and price control measures (F) in SADC are also on the rise as several countries started providing input support to the farmers. Subsidies are also linked with the WTO's domestic support. Countries in the region were able to justify their support on the basis of being least developed, food imports and food security. The detailed discussions on how these measures are observed in SADC trade will be discussed in the next section.

\footnotetext{
${ }^{3}$ Financial contribution by a government or government body to a production structure, being a particular industry or company, such as direct or potential transfer of funds (e.g. grants, loans, equity infusions), payments to a funding mechanism and income or price support.
} 


\section{SADC NTMs and their influence on agriculture trade}

\subsection{Introduction}

This section discusses the NTMs in SADC as compiled by the authors. It starts with justification and identification of the gap in compiling the NTM data. The shortcomings in analysis in this area as a result of absence or poor NTM data are discussed under the literature. Then methods and procedures of compiling the database are discussed and followed by the discussions of what came out of the database. And these results are discussed in terms of total SADC NTMs over the ten year period, by country, by products as well as by the type of NTM using the MAST classification.

\subsection{Previous studies on NTMs}

Generally the studies on NTMs rely on data from the TRAINS database or on business surveys which are conducted with the companies that are involved in trade (OECD, 2005; Donnelly and Manifold, 2005; Martinez et al, 2009). For work on SADC the TRAINS database was not applicable as it does not cover many countries in the region. The scarcity of NTM data in the SADC region limits the amount and quality of work that can be done in this area.

Mmasi and Ihiga (2007) have undertaken a survey of NTMs covering the EAC, SADC and COMESA. Their scope of work was limited to interviews with stakeholders and border officials. Other studies and surveys of NTMs in SADC countries were done by the WTO (2012), Charalambides and Gilson (2011), Mthembu-Salter (2007), institutions such as Imani (2007), TIPS (2007) and SAIIA (2007). The survey work by Imani (2007) covered eleven SADC countries. In this survey, the authors relied mostly on the respondents' information and their knowledge of existence of NTMs.

The end results of the Mmasi and Ihiga (2007) study were mainly identification of what was observed during the survey as key NTMs. The analysis of the consultancy work seemed to be focused on some aspects of NTMs, for example SPS, and not all of them. Furthermore, the survey work did not compile an audit of the NTMs, except for the efforts of Trademark Southern Africa (2011). The availability of data limited the research work to identification or analysis based on frequencies and coverage ratios. Frequency ratio identifies products affected by NTMs, and coverage ratio estimates share or value of imports affected by NTMs. However, these measures do not deal with the severity of NTMs or separate NTMs imposed by exporter from importer. Analysis based on this information will not adequately address some of the main concerns about NTMs or lead to informative policy making that seeks to address such challenges. To address NTMs decisively and for policy decisions to be 
implemented, it is necessary to know the role and impact of each individual NTM on specific products as well as the country imposing the NTMs.

Trademark Southern Africa started a process of recording NTMs at the border posts within SADC, EAC and COMESA (Trademark Southern Africa, 2011). The reporting of complaints is done by the traders or truckers as they experience challenges, and the matter is recorded to be taken further with the affected countries. There is also information on the notifications such as SPS and TBT to the WTO and fellow SADC partners (WTO, 2005). There is transparency in the process as all the information is made available online as well as contact details for each an every responsible institutions in the countries in case follow ups are necessary.

The work is however not sufficient to explain what really happened in the previous years. Furthermore, its focus is narrow as it hardly includes issues beyond the border. In other words, it barely scratches the surface in terms of what is happening with the NTMs. The classification of NTMs used has only eight categories compared to MAST classification that has sixteen chapters, and each individual chapter is divided into groupings with depth up to three levels. , The eight categories include the following:

- Government participation in trade and restrictive practices tolerated by governments,

- Customs and administrative entry procedures,

- Technical barriers to trade (TBT),

- Sanitary \& phyto-sanitary (SPS) measures,

- Specific limitations,

- Charges on imports,

- Other procedural problems, and

- Transport, Clearing and Forwarding.

One key shortcoming of this reporting system is that it totally excludes NTMs which are imposed by exporters (export taxes, bans, subsidies, and other measures imposed on their products). Furthermore the categories are too broad and therefore do not necessarily indicate the specific product that is affected. For example, some of the barriers that are reported on Trademark Southern Africa portal include information such as refusal to accept certain certificate or delays at border posts without indicating the affected products. Another weakness of the reporting system is that it will not include factors such as regulatory measures, state trading and licensing requirements because they are not necessarily part of what is happening at the border. However they are part of NTMs. Therefore the portal does not cover those measures, yet they do affect trade flows.

In order to address such shortcomings and gap, this paper provides detailed information on NTMs in SADC over eleven year period. Furthermore, the data is classified into the MAST taxonomy. The information was collected from gazetted documents from the governments of the seven SADC countries in this study, other survey reports, WTO notifications and policy briefs. Interviews were held with various government officials and institutions involved in trade, trade regulation and trade negotiations. There were also visits to some of the SADC border posts to observe what happens at the border when some of the consignments arrive, 
how they are handled, how long it takes to process the documents and other administrative issues of relevance.

The end result is a database of NTMs in SADC by country according to the MAST taxonomy. The database shows incidences of NTMs by country and by product. The database is a work in progress as it needs to be updated regularly. The NTMs are evolving and adapting with time, and therefore an NTM database should follow suit.

\subsection{Compiling SADC NTMs and Sources}

The database was compiled with information from several sources. These sources can broadly be categorised into three groups, namely WTO, governments and research reports. The WTO documents which were used include the notifications to the WTO such as SPS, TBT, schedules of concessions or commitment, trade policy reviews, monitoring reports and dispute reports. Government reports include policy documents, legislations and other gazetted information. Research reports cover information gathered from private institutions, unpublished and published research in journals, by consultants, non-governmental organisation and others. This also includes the information that was gathered in the interviews with government officials in several SADC countries. All information, particularly from interviews and private research was checked and confirmed with authorities and through other official documents to make sure that was included are not just opinions. Then the database was developed following the MAST classification.

The MAST classification was greatly useful in simplifying data collected. Given that all known NTMs have categories within this classification, it becomes easier to compile it. In all SADC countries for which data was gathered, none had a single repository of NTM information. Furthermore, laws and regulations affecting trade are enacted by different government agencies. Figure 1 provides a summary of the process followed in building the SADC NTM database. 


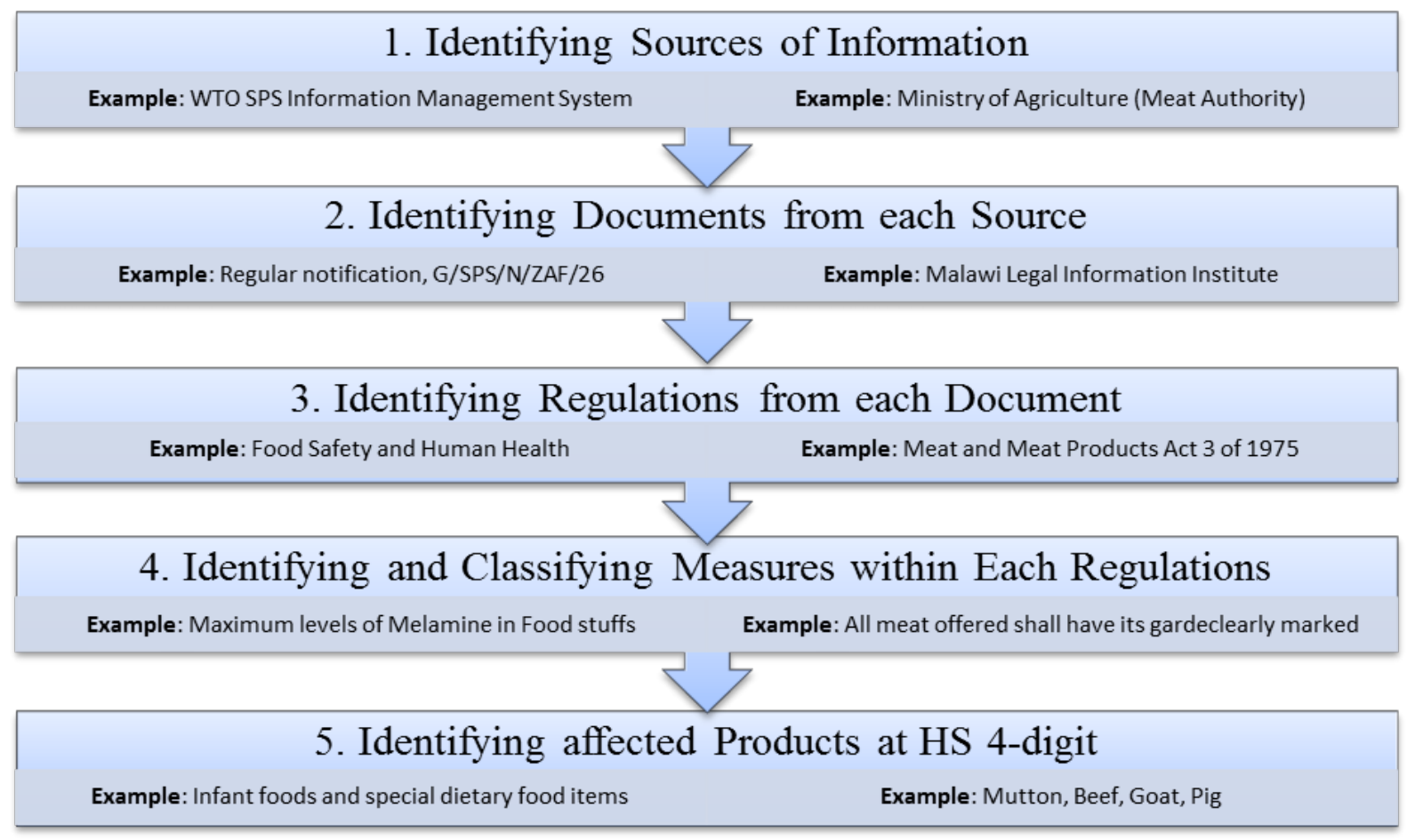

Figure 1: $\quad$ Process of compiling SADC NTM data

Most of the data was gathered through documentation gathering. In the first step, sources of information were identified from various government agencies and institutions. The sources of data varied, depending on the country. In many countries, information is published online. Some countries publish information on the official government website, others on the parliament websites. Some of the documents were gathered from the regional Secretariats, i.e. the SACU Secretariat in the case of SACU countries, SADC Secretariat, COMESA, EAC, and Indian Ocean Community (IOC). The WTO SPS management system was helpful in obtaining those regulations which were already notified.

In the next documents which contain regulatory measures, such as Acts, government gazettes and other government regulations, were collected in step two. An inventory of the documents on trade regulations was also compiled to continue the process of database building. Trade and other regulations affecting trade are published in various documents and websites. Some regulations are published in one or several documents. For example, the agency responsible for trade promotion would publish the regulations, and the government department responsible would do the same. Some examples of the document titles include Import and Export Control Act, Tobacco Act, Food Act, Animal and Disease control. The WTO policy documents have notification numbers which makes it easy to find them on the WTO database of documents.

In the third step, regulations arising from such documents were identified. One document may contain several regulations. All regulations which were identified were recorded. Then, in that way, NTMs were matched with the products. In some instances, a regulation may be called a law, in others an Act, sometimes an ordinance, directive, an order, notification or a decree. Attempts were made to identify all such regulations. This included having to look at 
additional and separate documents to verify whether what is deemed to be a regulation, indeed applied as such.

In the fourth step, those regulations were then classified into various categories. Once all measures within each regulation were identified, the process of classifying them then started. This implied that each regulation needed to be clearly read through to find the corresponding NTM code. Some of the regulations were clearly straightforward, but others presented great challenges in deciding which NTM code each belonged to. For example, the codes for most measures on export (category P) and rules of origin (category O) were fairly easy to find, as there are very few of those categories. In some cases, a regulation may fit into two categories. For example, the labelling requirement for food products does fit as an SPS requirement (A31), as well as a TBT (B31). The same thing applies to marking - A33 or B33. In such cases, one code was selected.

Lastly, the products affected were identified. The challenges come were the regulations are applied on a product which cannot be differentiated at HS 4-digit level. For example, some regulations will be applicable only to yellow or white maize. However, in the harmonised system (HS) nomenclature at HS 4-digit, the two are not distinguished from one another. In that case, the regulation will be coded on the product as if it applies to both.

The period covered for compilation of NTMs is 2000 to 2010. These NTMs were compiled for agricultural products only. The products included were those covered by the WTO definition of agricultural products, and were defined at HS 4-digit level. In total, NTMs on 247 products were compiled for ten SADC countries. These countries included the four SACU members, Malawi, Mauritius, Mozambique, Tanzania, Zambia and Zimbabwe.

\subsection{SADC NTMs over time}

Overall more than 4400 NTMs were identified in the agricultural sector for SADC by end of the year 2010. However, the numbers of NTMs indicated in 2000 were not all introduced that year, but an accumulation until the end of that year. Basically all the years are accumulation as NTMs are hardly reduced, with exception of temporary bans. Figure 2 shows that SADC NTMs on agricultural products in the year 2000 were just over 2000. This was an aggregation of all ten SADC countries included in the study. Furthermore, Figure 2 shows a steady upward sloping trend, implying growth in NTMs between the years 2000 and 2004. One year before the launch of SADC FTA there was almost twice the number of NTMs as there were at the beginning of the trade protocol implementation. There close to 4000 NTM incidences in 2007. Then another steady rise is observed from 2008 to 2010, showing that even after the FTA was launched, SADC countries continued to add NTMs. 


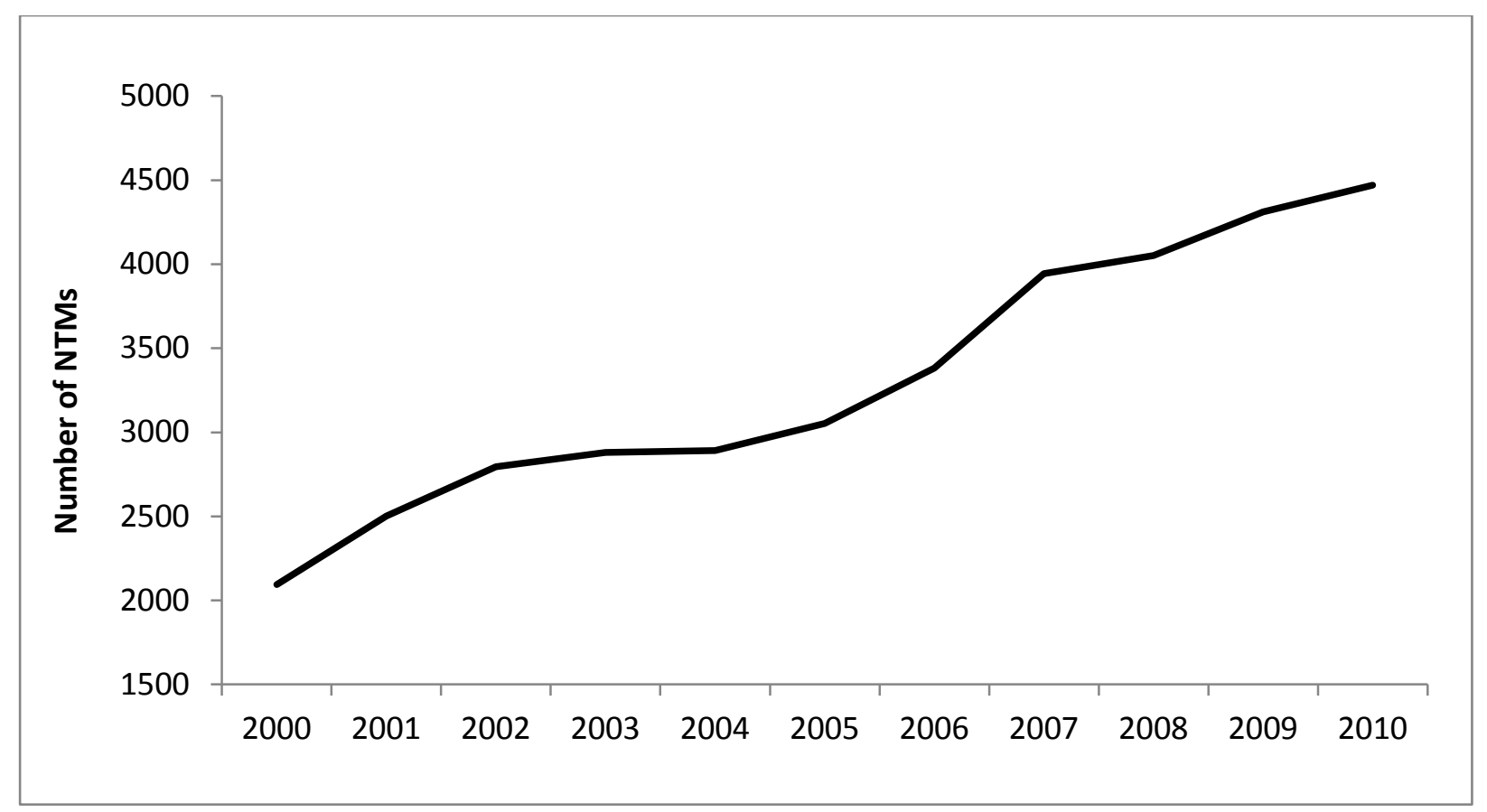

Figure 2: Aggregated SADC NTMs from 2000 to 2010

Source: NTM Database compiled by authors, 2012

The sharp rise of NTMs towards the year 2007 is associated with a response to the deadline of the launch of the SADC free trade area (FTA). SADC FTA was launched in 2008, so may be countries were waking up to the reality that tariffs needed to be reduced substantially between 2005 and 2008. More than two thirds of SADC countries had back-loaded their phase down schedules, so at that time there were still many tariff lines to be reduce. That may have motivated those countries to increase the use of NTMs. Furthermore, this rise is linked to the eventual realisation that tariffs as a means of protection is no longer an option. This is further supported by the fact that some of the countries, such as Malawi, Tanzania and Zimbabwe that were supposed to fully implement the SADC trade protocol and FTA have not done so for different reasons (SADC, 2011).Furthermore, over this period there has been a number of ad hoc policies such as import bans, quantitative restrictions and other policy responses to the global economic crises around the same period (World Bank, 2012).

\subsection{NTM by Country}

As it was explained in the previous section, application of NTMs was on the upward trend since the year 2000. However, not all countries were increasing the NTMs at the same rate. Figure 3 shows NTMs by the ten SADC countries for the first year (2000) and last year (2010) of the study period. This helps to provide a comparison of where the countries were in at the beginning, relative to 2010. It is evident that some countries started at very low levels of NTMs.

Figure 3 shows that six SADC countries had fewer than 200 NTMs on agricultural products. These were Malawi (MWI), Mauritius (MAU), Mozambique (MOZ), Tanzania (TAN), 
Zambia (ZMB) and Zimbabwe (ZWE). All these countries mid-loaded and back-loaded their tariff phase down schedule (SADC Secretariat, 2000). The remaining countries started at high levels of NTMs. They all had NTMs of 200 and higher in 2000. Coincidentally, all of them were SACU members. South Africa (ZAF) was a clear leader with more than 400 NTMs, followed by Swaziland (SWA) while Botswana (BWA) had the least NTMs amongst SACU countries with 220.

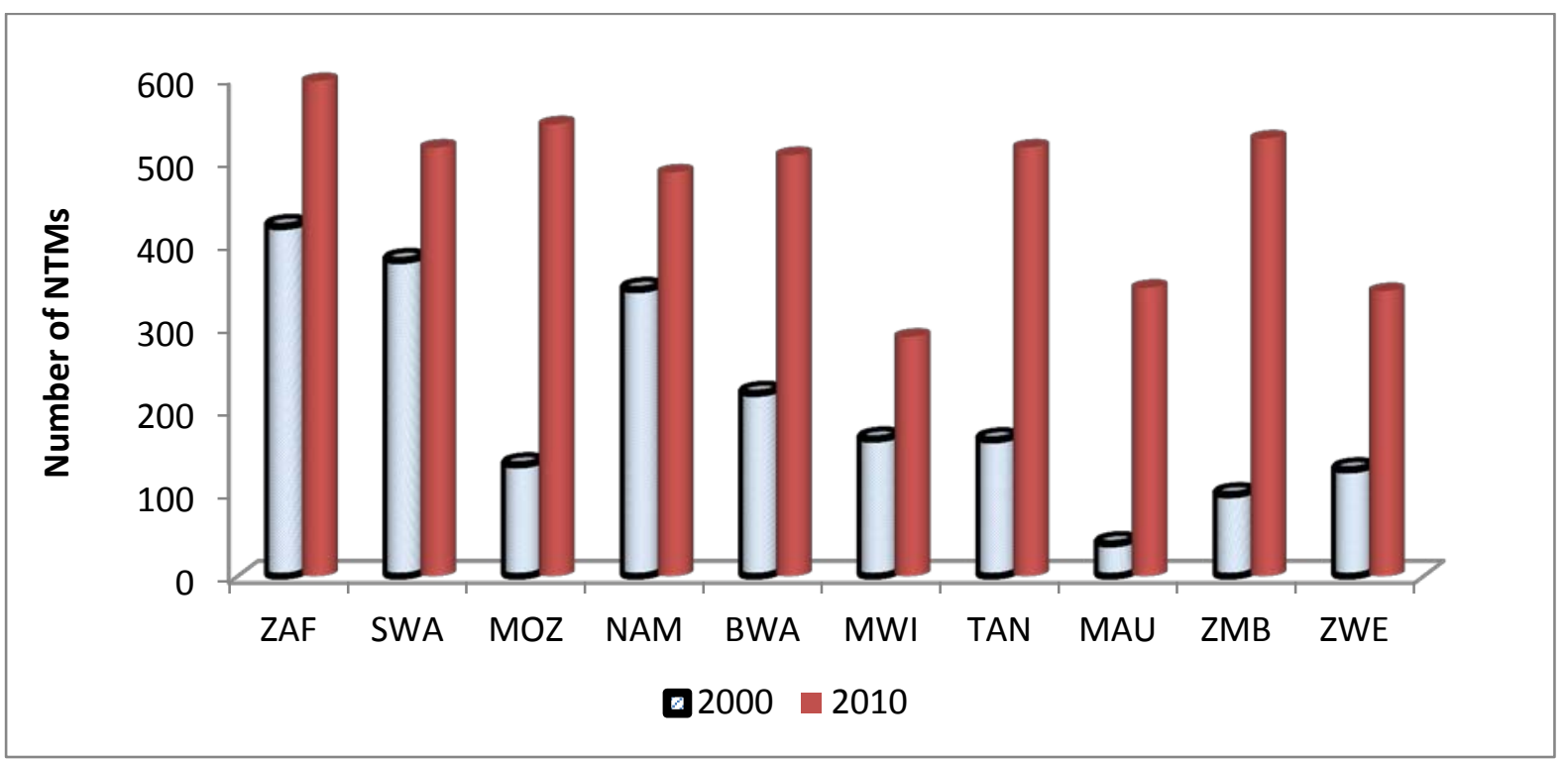

Figure 3: SADC NTMs by country for the years 2000 and 2010

Source: NTM Database compiled by authors, 2012

In 2010 South Africa was still the leader with close to 600 NTMs applied on the imports of agricultural products. About $80 \%$ of these NTMs were contributed by three categories. SPS measures (category B) contributed 37\%, then licensing, quantitative restrictions and other prohibitions (category E) accounted for 22\% and TBT measures (category A) added 18\%. Most of these were on products such as beverages, spirits and vinegar (17\%), Fruits (15\%), Meat products (14\%) and Dairy products (13\%). Five other countries had NTMs around the 500 mark, and these are Zambia, Tanzania, Botswana, Namibia and Swaziland. Malawi, Mauritius and Zimbabwe had relatively low NTMs in 2010 of around 300 and lower. Malawi is the country that applies the least NTMs. By the 2010 it still had less 300 NTMs, which was lower that what other countries had a decade ago.

SACU did not only start at high levels of NTMs, but it also increased the use of NTMs substantially over the period. NTMs are introduced at country level and not all of them are motivated by trade policy. So, despite SACU having common trade policies, NTMs are not necessarily expected to be similar. The NTMs of SACU countries are attributed to the SACU Agreement of 2002 which established industrial policy (SACU, 2004). This led to introduction of measures such infant industry in subsectors such as dairy, beverages and meat (Charalambides and Ngwenya, 2011 and Grynberg, 2011) in Swaziland, Botswana and Namibia. 
This does not imply that other countries have not done anything to grow their NTM base. Most countries were still below SACU countries in 2010 mainly because they have started from a very low base. However, when one looks at the average growth of NTMs by all the countries, it becomes apparent that all countries had intentions to make use of more NTMs. Zambia was the fastest increasing country with a growth of more $430 \%$ over the ten year period. This implies that on average, Zambia was adding more than 43 NTMs that affect agricultural products. It was followed by Mozambique with an average of 41 new NTMs per year over the ten year period, and then Tanzania with 35. Malawi is also the least in terms of adding NTMs, with an average of 12 NTMs per year.

There is a noticeable relationship between the countries' use of NTMs and tariff reduction. First, the countries which were front-loading the tariff phase down, SACU started at higher levels of NTMs than any other country. Secondly, countries which were back-loading (Malawi, Mozambique, Tanzania and Zambia) and mid-loading (Mauritius and Zimbabwe) started increasing their NTMs at about the same time where major reductions were required to happen, that is from 2005. Thirdly, the country that has the least NTMs in terms of numbers and growth, has not adjusted its tariff schedule since 2000 (Southern African Trade Hub, 2011). The implication is that, since there was no tariff adjustment, one can argue that they didn't see the need to adjust NTMs. Overall, the pattern of NTM use is consistent with the tariff reduction, and therefore the two can be considered to be substitutes.

\subsection{NTM by Products}

The NTM counts for products were aggregated at the HS 2-digit level for reporting. However, the database has a count at HS 4-digit. In the year 2000, four product groups at HS 2-digit had NTMs of around 200 by all SADC countries. These were dairy (cheese, milk, yoghurt and others), beverages (wine, alcohol and spirits), fruits and meat products. These groups are followed by vegetables and cereals with NTM numbers of between 100 and 200 . Figure 4 shows that the rest of the product groups had NTMs of less than 100 in the first year of the period of analysis. 


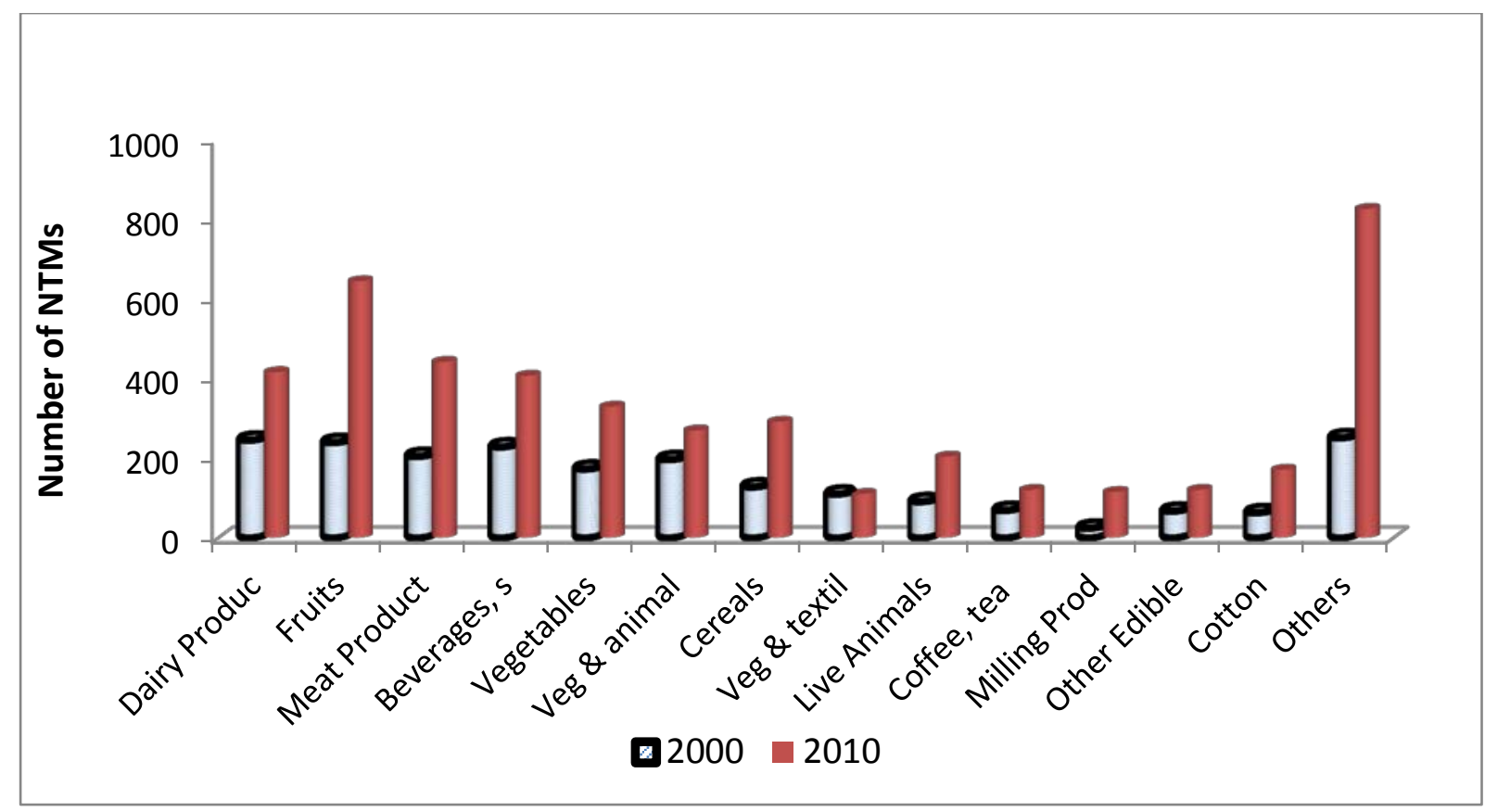

Figure 4: NTMs by Product groups for the years 2000 and 2010

Source: NTM Database compiled by authors, 2012

By the year 2010 fruits have taken over as the leading product group in terms of number of NTMs. By that that time the group had accumulated a total of more than 600 NTMs. The product groups following fruits at a long distance are dairy, beverages and meat products. They had accumulated about 400 NTMs. Cereals, vegetables and live animals are the third tier of product groups in terms of the use of NTMs.

In summary, all products have increased their NTMs. This is also reflected by the last category, "others" which is an aggregation of all products which are outside the top twelve product groups. The highest growth rates were in products such as cocoa and cocoa products, vegetable materials, animal skins and others. Like other products, in the year 2000 most of them had few NTMs, but then accelerated the use of over time.

Another way of looking at how NTMs have increased by product groups over the period is by evaluation the growth rates. Starting with those that started from a high base (of more than 200 NTMs in 2000), fruits were clearly the fastest growing group with about $170 \%$ over the period. That implies on average 40 NTMs were added on fruits by the SADC member countries per annum. Meat products had a growth of about $120 \%$. Those products growing from a low base include tea, coffee and spices as well as fats and oils of vegetables and animals (HS 15) both growing at a rate of more than $600 \%$ over the period. However, the fact that the far right bar of other products (an aggregation of products with fewer NTMs in 2000) increased substantially implies that almost all products have realised some increases in the use of NTMs. 
In 2010 the total number of NTMs had grown to 4470. Two of the top three had lost their share and only fruits maintained the same share as in 2000, and remained the leader. The share of both dairy and beverage products declined from 2000 to less than $10 \%$ in 2010 . The shares of products such as meat and cereals have not changed. Fats of vegetables and animal oils have tripled its share of NTMs over a decade. All products appear to maintain about the same share for both periods, except in the case of fruits, vegetables and animal fats.

\subsection{NTM by Category}

The use of NTMs by category shows that SPS measures were preferred in 2000. Figure 5 depicts that out of all 2094 NTMs which were compiled in the 10 SADC countries in 2000, 485 were SPS measures. This represented more than one fifth of all NTM categories. They are followed by the SADC rules of origin; licensing, quotas and bans; and export measures. The use of rules of origin and export measures is really a concern for regional integration. This is mainly because that they are supposed to facilitate intra-regional trade. The fact that their use is so prevalent, yet SADC trade has not improved implies that they may be serving the opposite of what SADC aims to achieve in terms of regional integration.

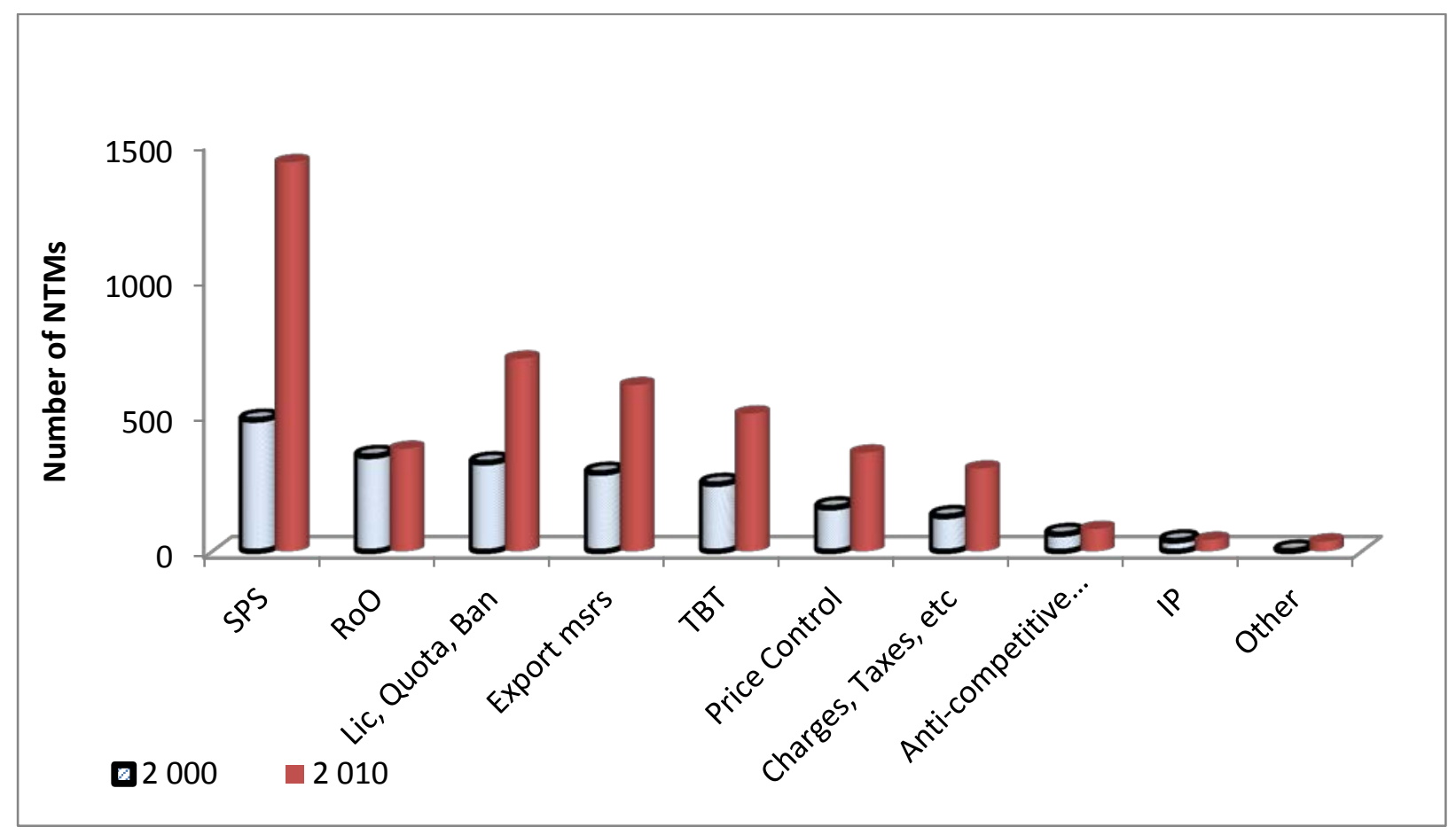

Figure 5: SADC NTMs by category

Source: NTM Database compiled by authors, 2012.

Figure 5 shows that SADC countries consolidated their use of SPS measures over the period. By the year 2010 SPS measures have increased from less than one quarter of all NTMs used to more than one third. Licensing, quotas and bans increased as well as export measures increased substantially. Rules of origin have not increased in numbers, mainly because SADC only changed once over the period, in 2007 (Southern African Trade Hub, 2011). That adjustment has not changed the rules substantially. 


\subsection{Nature of SPS measures applied in SADC}

Application of SPS measures was expected to dominate most NTMs due to three reasons. First, these are regulations for food safety, animal and plant health protection (WTO, 2010a and Martinez, 2009). Therefore they are expected to be in majority for agricultural products. The second reason has to with the fact that their use is allowed by the WTO as long as it can be justified. Thirdly, when these measures applied, they tend to be accompanied by other procedural requirements, which add another layer of measures (WTO, 2012). An example of the procedures may require that if the importer introduces a measure, in order for the supplier to comply with the measure, the exporter may be required to do inspection, ensure traceability, labelling and packing.

Half of the 1400 SPS measures applied in SADC are accounted by five sub-categories, out of a total of 30 sub-categories. About 20\% of applied SPS in SADC are classified as systems approach (Sub-category A130). Figure 7 below shows number of the SPS sub-categories as applied by SADC members. This sub-category SPS is applied in a combination of one or two independent SPS measures. For example, to check whether the exporter complies with the requirement, both the inspection and the testing may need to be done. Some measures may include pre- and post-harvest treatments.

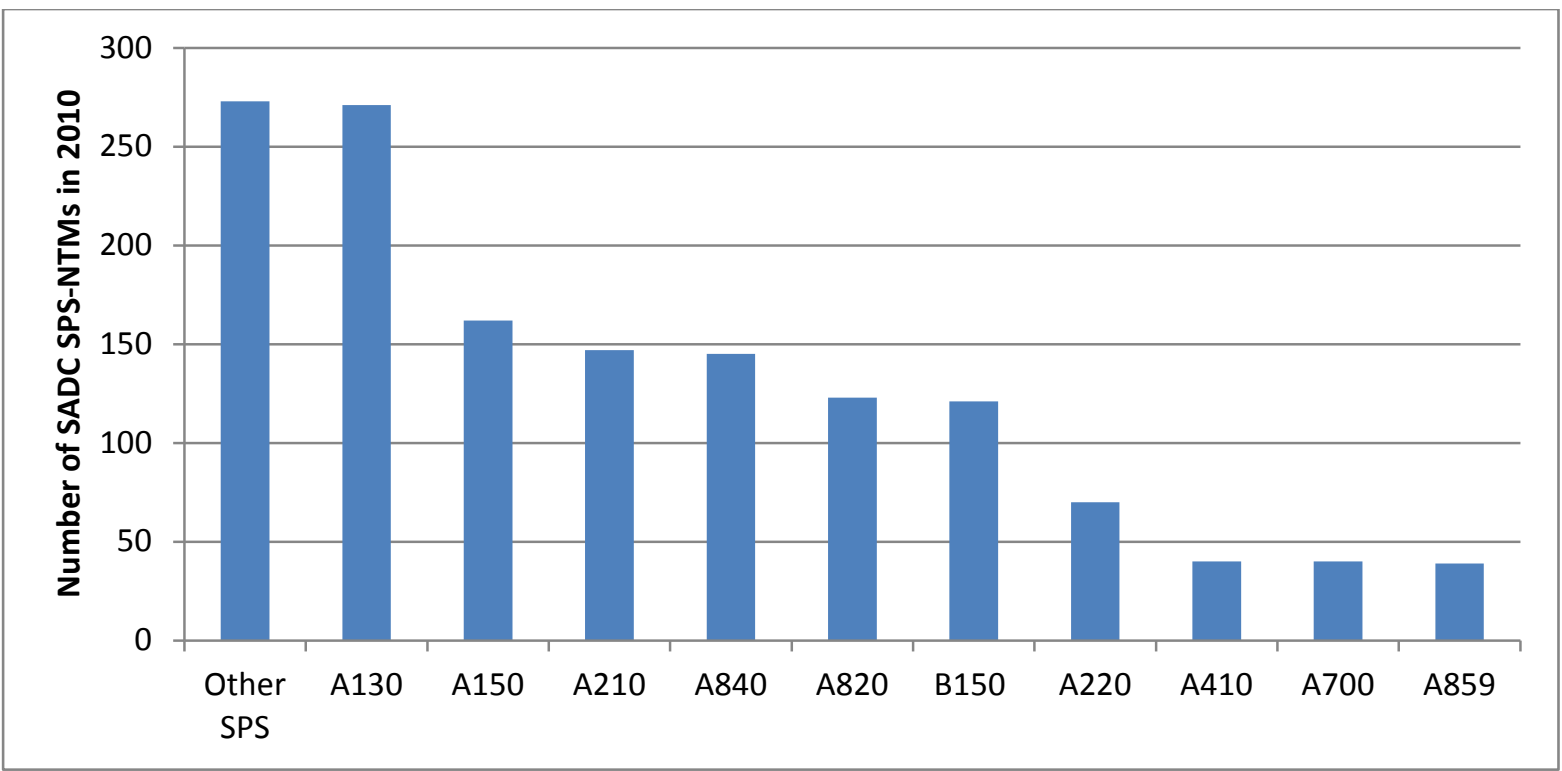

Figure 6: Breakdown of SPS measures applied by SADC countries, 2010

Source: NTM Database compiled by authors, 2012.

Registration requirements (Sub-category A150) by importers account for $11 \%$ of all SPS measures in SADC. This applies to importers of products affected identified SPS measures. In the registration, importers may have to comply with certain requirements, provide some documents and even pay a certain amount in registration fees. Registration may also be at multiple institutions, i.e., Ministry of Health, Agriculture, Trade and Industry or agencies of such Ministries. 
Tolerance limits for residues (sub-category A210) and inspection requirements (sub-category A840) account for 10\% of SPS measures each. UNCTAD (2010) defines tolerance limits for residues as a measure that establishes a maximum residue limit (MRL) or "tolerance limit" of substances in foods and feed, which are used during their production process but are not their intended ingredients. Requirement for product inspection in the importing country may be performed by public or private entities. In some cases it may be similar to testing, but does not include laboratory testing. The other half of SPS measures is contributed by 25 other subcategories of NTMs.

In summary, the use of SPS measures is linked with the fact that WTO rules allow them. As long as they do meet the requirements, then members can apply them, and as long as they are also notified to the WTO. Rules of origin and export measures are worrying as they seem to be contradicting the objectives of SADC. They are supposed to help promote regional trade, but there is no evidence of such outcomes. However, the fact that share of rules of origin have declined by half in 2010 may be an encouraging sign that if many NTMs are sanctioned by regional institutions, may be they may start declining or only those that are necessary will be introduced.

\section{Conclusion}

The trade policy challenges that are accompanied by the use of NTMs keep increasing. This phenomenon is observable at global, regional and national levels. These challenges intensify as tariffs are being reduced. The problem is that some of the NTMs are not transparent, and therefore difficult for trading partners to comply with or prepare for them. They are also aggravated by the fact that some of the measures used are legitimate while others are purely to reduce competition from foreign products. This adds to the complications of NTMs. The aim of this paper was to shed some light on NTMs used on SADC agricultural products.

SADC trade performance of agricultural products was shown to be performing poorly. The value on intra-SADC imports when compared to those from non SADC members appeared to be lagging behind. The growth rates of the two sources of imports also showed that non SADC imports overall were growing at a faster rate. When intra-SADC import share was compared with the rate of tariff reduction, once again there was indication that the SADC share of imports has not improved as expected. Therefore, tariff reduction did not result with high intra-SADC trade performance. Other factors such as NTMs may have a role to play in this lack of response from the SADC trade such as lack of productivity or competitiveness. So the role and use of NTMs in SADC needed to be clearly understood.

The compiled information confirms that indeed the use of NTMs on agricultural products in SADC has increased between the years 2000 and 2010. Ten SADC countries had an aggregate of about 2000 NTMs in 2000, and by 2010 that number had more than doubled. This implies that, at least 230 NTMs were introduced per year. Furthermore, it means that on average, each of the 250 agricultural products (at HS 4-digit level) faces about 17 NTMs in 2010. 
The breakdown of SADC NTMs by country reveals that SACU members have more NTMs, and they also started with a very high number in 2000. This has to do with the fact that in terms of the SADC tariff phase down, SACU needed to start their tariff phase down earlier than all countries. The rest started their phase down three to five years later. There is also an inverse relationship between tariff phase down and increase of NTMs. This seems to be supported by the fact that when non-SACU countries needed to cut their tariffs, there was evidence of increasing NTMs amongst those countries. Another observation is that Malawi which has the least NTMs, didn't adjust the tariff schedule according to the SADC phase down requirements, and therefore didn't see the need to increase NTMs.

High incidences of SACU NTMs are consistent with the use of such measures around the world (Nicita, 2011). Developed countries with highly diverse economy tend to have high incidences of NTMs. This is because such measures are applied for different products. Within SADC, SACU was classified as a developed group during the implementation of the trade protocol. Furthermore, SACU's implementation of industrial policy meant that some of these measures were needed to provide some protection for priority sectors (Charalambides and Ngwenya, 2011).

The use of NTMs by product was high for dairy, meat, beverages and fruit product groups in 2000. By 2010 fruits experienced a more application of NTMs, relative to the rest of agricultural products. Besides, fruit, generally all products faced more NTMs relative to 2000. However, the use of NTM by category shows that mainly SPS measures were the most used. This was both for the year 2000 and they continued to rise over a decade. The rationale behind is that they are allowable by the WTO as long as they can be justified. Rules of origin and export measures were very high in 2000, however there was no real change in the number of rules of origin and eventually they declined in percentage terms.

The NTMs legitimate or not have potential to restrict trade. Their application needs to be monitored and understood so that trading partners can comply. However, if there is no transparency in their use, and they remain ad hoc, then they are likely to reverse the gains made in trade liberalisation and other negotiations. For SADC, measures applied on export and in rules of origin are worryingly high and may be destruction to regional integration goals. One of the key recommendations is that there should clear inventory and publication of the NTMs when they are introduced. This will promote transparency around these measures.

One encouraging factor is that the rules of origin were adjusted only once and that has let to their decline in percentage terms. The reason behind that is because they cannot be unilaterally applied, but must be sanctioned by the regional secretariats. Therefore, harmonisation of the NTM measures should follow a similar route used in the rules of origin. Furthermore, countries need to invest in the human resources that deal with the recording, evaluation and implementation of NTMs. This is even more relevant to SPS measures which need to be supported by scientific evidence before they are applied. So furthermore investment in education, research and development is very important. Finally, NTMs are 
trade policy measures and they will continue to be discussion points. There is a need to continue working on them, identifying, quantifying and adjusting policies to promote trade in the region.

\section{References}

Bacchetta, M., Richtering, J. and Santana, R. (2012), "How much Light do WTO Notifications shed on NTMs?”, in Cadot, O. and Malouche, M. (eds.), Non-Tariff Measures: A fresh look at trade policy's new frontier, Washington, D.C. and London, World Bank and Centre for Economic Policy Research.

Baldwin, R. E. (1970), Nontariff Distortions in International Trade, Washington, D.C., the Brookings Institution.

Cadot. O and Gourdon, J (2012) Assessing the price-raising effects of non- tariff measures. CEP II Working Paper No 2012 - 16. Paris.

Cadot, O. and Malouche, M. (eds.), Non-Tariff Measures: A fresh look at trade policy's new frontier, Washington, D.C. and London, World Bank and Centre for Economic Policy Research. The World Bank, Washington DC, USA.

Cadot, O., Molouche, M and Saez, S. (2012), Streamlining Non Tariff Measures. A Toolkit for Policy Makers. ISBN : 978-0-8213-9510-3. The World Bank, Washington DC, USA.

Charalambides N and Gillson N. (2011), “Addressing Non-Tariff Barriers on Regional Trade in Southern Africa”; in O. Cadot and M. Malouche, eds., Non-Tariff Measures: A Fresh Look at Trade Policy's New Frontier; Washington, DC/London: The World Bank/CEPR.

Charalambides, N and Ngwenya, K.(2011), Achieving Balanced Industrial Development Within a Regional Setting: Challenges and Pitfalls, Imani Development, Gaborone, Botswana

Donnelly, W. A. and Manifold, D. (2005), “A Compilation of Reported Non-Tariff Measures: Description of the Information”, Washington, D.C., US International Trade Commission, Office of Economics Working Paper 2005-05-A.

Gillson, I (2011), Non-Tariff Barriers to Sub-Saharan African Trade in Food Staples: Opening Regional Markets to Promote Food Security and Price Stabilization; Washington: The World Bank, 2011.

Gourdon, J, and Nicita, A (2012), "Non-Tariff Measures: Evidence from Recent Data Collection.” In Non-Tariff Measures-A Fresh Look at Trade Policy's New Frontier, ed. Olivier Cadot and Mariem Malouche. London/ Washington, DC: Centre for Economic Policy Research/World Bank.

Grynberg, R (2011) "The Price of Poultry and Beef." Discussion Paper, Botswana Institute of Development Policy Analysis (BIDPA). Gaborone, Botswana. 
Imani Development (2007), 2007 Survey of Non Tariff Barriers to Trade, July 2007. www.imanidevelopment.com. Johannesburg, South Africa.

International Trade Centre (ITC) (2003), Business Guide to the World Trading System. Second Edition. Geneva, Switzerland. International Trade Centre, UNTAD/WTO.

Lloyd, P.(1996), “The Changing Nature of RTAs” in B. Bora and C. Findlay (eds), Regional Integration and Asia Pacific, Melbourne, Oxford Press.

Martinez, A., Mora, J. and Signoret, J. E. (2009), “The CoRe NTMs Database: A Compilation of Reported Non-Tariff Measures”, Washington, D.C., US International Trade Commission, Office of Economics Working Paper 2009-12A.

Mmasi J and Ihiga S. (2007), A Survey Of Non-Tariff Barriers That Affect Tanzanian Imports and Exports Within EAC, SADC and COMESA Countries. Accessed May 2012. http://ntb.africonnect.com/media/tanzania.pdf.

Mthembu-Salter, G. (2007), The Cost of Non-Tariff Barriers to Business along the NorthSouth Corridor (South Africa-Zimbabwe) via Beit Bridge -a Preliminary Study. Trade Policy Report No. 20, South African Institute of International Affairs (SAIIA). Johannesburg, South Africa

Multi Agency Support Team (MAST) (2009), "Report to the Group of Eminent Persons on Non-Tariff Barriers.” Presented at the Group's meeting of November 5, 2009. United Nations Conference on Trade and Development, Geneva, Switzerland.

Nicita, A.(2011), What Information about NTMs do we Have and What are we Missing? Paper presented at the EAAE Conference in Zurich. September 2011.

Nicita A.and Gourdonn, J (2012),A preliminary analysis on newly collected data on nontariff measures. UNCTAD/ITCD/TAB/54, Geneva, Switzerland

Organisation for Economic Co-operation and Development (OECD) (2001), Measurement of Sanitary, Phytosanitary and Technical Barriers to Trade, Paris, France

Salvatore, D. (2011), International Economics: Trade and Finance: Tenth Edition. John Wiley and Sons. Singapore.

South African Institute of International Affairs (SAIIA) (2007), Non-tariff barriers in Southern Africa - towards a Measurement Approach. Johannesburg, South Africa.

Southern African Customs Union (SACU) (2004). The 2002 Southern African Customs Union (SACU Agreement. Windhoek, Namibia. 
Southern African Development Community (SADC) (2004), SADC Protocol on Trade. Gaborone Botswana.

Southern African Development Community (SADC) (2011), Desk Assessment of the Regional Indicative Strategic Development Plan 2005 - 2010. Gaborone Botswana.

Southern African Development Community (SADC) (2012), SADC Towards a Common Future. Gaborone Botswana.

Southern African Trade Hub (SATH) (2011), Technical Report: 2011 Audit of Implementation of the SADC Protocol on Trade. USAID Southern African Trade Hub. August 2011. Gaborone, Botswana.

Trade and industrial Policy Strategies (TIPS)(2007), Non Tariff barriers in SADC. Trade Performance Review 2007: Chapter 6: Non tariff barriers in SADC. Pretoria, South Africa.

TradeMark Southern Africa (2011), TradeMark Southern Africa (TMSA), Briefing Information, October 2011. Pretoria, South Africa.

United Nations Commodity Trade Statistics Database (UN COMTRDE) (2012), Trade Statistics accssed via World Integrated Trade Solutions (WITS), UN Comtrade New York: United Nations, USA.

United Nations Conference on Trade and Development (UNCTAD) (2010), Non-Tariff Measures: Evidence from Selected Developing Countries and Future Research Agenda. Developing Countries in International Trade Studies. United Nations Conference on Trade and Development. Geneva, Switzerland.

United Nations Conference on Trade and Development (UNCTAD)( 2012),. Non-Tariff Measures to Trade: Economic and Policy Issues of Developing Countries. United Nations Conference on Trade and Development. Geneva, Switzerland.

United Nations Conference on Trade and Development (UNCTAD)( 2012a),. International Classification of Non-Tariff Measures. United Nations Conference on Trade and Development. Geneva, Switzerland.

Wolfe, R (2003), Regulatory Transparency, Developing Countries and the World Trade Organisation (WTO). World Trade Review. 2:2 (July 2003), 157 -82.

World Bank (2012), De-fragmenting Africa: Deepening Regional Trade Integration in Goods and Services. Washington, DC: World Bank.

World Trade Organisation (WTO)( 1995),Agriculture - Explanation of the Agreement. Annex 1 of the Agreement, Product Coverage. The World Trade Organisation Geneva, Switzerland. 
World Trade Organisation (WTO)( 2005), World Trade Report, 2005. Trade, Standards and the World Trade Organisation (WTO). The World Trade Organisation Geneva, Switzerland.

World Trade Organisation (WTO) (2008), World Trade Report, 2008. Trade in a Globalising World. Geneva, Switzerland. World Trade Organisation.

World Trade Organisation (WTO) (2010), World Tariffs Profile 2006 - 2010. Geneva, Switzerland. World Trade Organisation.

World Trade Organisation (WTO) (2010a), World Trade Organisation Agreements Series. Sanitary and Phytosanitary Measures. ISSN 1020-4768. Geneva, Switzerland. World Trade Organisation.

World Trade Organisation (WTO) (2012), World Trade Report 2012. Trade and Public Policies: A closer look at the Non-Tariff Measures in the $21^{\text {st }}$ Century. Switzerland. World Trade Organisation.

\section{ADDENDUM: List of documents used in compiling the SADC NTM Database}

\section{Botswana}

Botswana Agricultural marketing Board Act 1974. Available at: http://www.elaws.gov.bw/docs/ statutes/Botswana\%20Statute\%20Law\%201974.pdf (Accessed: 16 April 2016).

Control of goods (importation of sugar) regulations under section 3, 1 January 1985. Available at: file:///C:/Users/User/Desktop/ch46-07.pdf (Accessed: 16 April 2016).

Control of goods (Sugar exportation regulation) under section 3, 14 September 1979. Available at: file:///C:/Users/User/Desktop/ch46-07.pdf (Accessed: 16 April 2016).

Control of goods, prices and other charges Act (Control of goods Act [import and export of agricultural products) regulations under section 3, 25 November 1985. Available at: file://C:/Users/User/Desktop/ch4607.pdf (Accessed: 16 April 2016).

Control of goods, prices and other charges Regulation. 1979. Available at: file://C:/Users/ User/Desktop/ch4607.pdf (Accessed: 16 April 2016).

Customs and Excise (Act Cap 50:1) amended 2001. Available at: http://www.burs.org.bw/phocadownload/Revenue laws/CAP\%205003\%20Customs\%20and\%20Excise\%20Duty\%20Act.pdf (Accessed: 16 April 2016).

Pest and Diseases Act of 1966, Chapter 30:02. Available at: http://www1.eis.gov.bw/EIS/ Policies/Environmental\%20Policies/CAP\%2035-02\%20Plant\%20Diseases\%20and\%20Pests\%20Act.pdf

(Accessed: 16 April 2016).

WTO document G/TBT/BWA/1,13 November 2008.

WTO. 2008. Botswana Trade policy review.

\section{Malawi}

AECOM International Development. (2011). Technical Report: Regulatory Environment for Animal Feeds in Zambia, Malawi, Mozambique, Zimbabwe, Namibia and Botswana.

Mozambique Animal disease act 1990.

Animal Production Department, Government of Mozambique (2010). Livestock Statistics in Mozambique.

Maputo, Mozambique.

CEPAGRI .2009. Ministry of Agriculture: Agriculture Promotion Centre.

FAO and WFP . 2010. Crop and Food Security Assessment Mission to Mozambique, August 2010, Rome, Italy. FAO. 2011. Food and Agricultural Organisation Statistics. Rome, Italy.

International Fund for Agriculture Development (IFAD).2010. Country programme evaluation: Republic of Mozambique. 
Matay, C. 2005. Towards a regional approach to biotechnology policy in Southern Arica.

Meat and Meat Product Act 1975. Available at: http://malawilii.org/mw/consolidatedlegislation/ 6702/meat_meat_products_act_pdf_21082.pdf (Accessed: 16 April 2016).

Milk and Milk Product Act 1986. Available at: http://faolex.fao.org/docs/pdf/mlw21744.pdf (Accessed: 16 April 2016).

Nang'ayo, F. 2006. The status of regulations for genetically modified crops in countries of Sub-Saharan Africa.

Overseas Development Institute. 2009 Interim Economic Development Partnership Agreements between the EU and African States/: Contents, challenges and Prospects.

Promar Consulting.2011. Fact-finding Survey for the Support of Aid to Developing Countries The Cassava Industries in Mozambique and Tanzania: PRODUCTION, PROCESSING, DISTRIBUTION AND

CONSUMPTION OF CASSAVA AND ITS RELATED POLICY CHALLENGES

United Nations Conference on Trade and Development (UNCTAD) .2006.An investment guide to Mozambique: Opportunities and conditions .Geneva, Switzerland.

United Nations Industrial Development Organisation, 2008. Capacity building for aflatoxin management and control in groundnuts in Malawi.

\section{Mauritius}

Bowen \& Herrou-Aragon. 2003. Analysis of Mauritius's Trade policies in 2003.

Forum for Agricultural Research in Africa (FARA). 2011. Status of Biotechnology and Biosafety in subSaharan Africa: A FARA 2009 Study Report. FARA Secretariat, Accra, Ghana. [Affected products found in country report].

IMANI Development Consultant. 2004. Review of Dairy Industry in Mauritius. Final report, June 2004.

IMANI Development Consultant. Review of Dairy Industry in Mauritius. Final report, June 2004.

IMANI Development. 2007 update Survey of Non-Tariff Barriers to Trade: Mauritius.

Neelia, S.A. 2007. Food inspection in Mauritius wit focus on fruit and vegetables. 12th International Training Course 'Harmonisation of Fruit and Vegetables Quality Assessment'.

PART VII - FROZEN FOOD [Online] Available at: http://www.gov.mu/portal/goc/moh/file/ fpart7.doc. [Downloaded 2012-06-05].

Part XI -cereal, grain, pulse, legume, cereal product, starch and bread [Online] Available from: http://www.gov.mu/portal/goc/moh/file/fpart11.doc [Downloaded 2012-06-05].

PART XII - TEA, COFFEE, CHICORY, COCOA, and CHOCOLATE DRINK [Online] Available from: http://www.gov.mu/portal/goc/moh/file/fpart12.doc [Downloaded 2012-06-05].

Part XIV PART XIV - EGG AND EGG PRODUCT.doc [Online] Available from: http://www.gov.mu/portal/goc/moh/file/fpart14.doc [Downloaded 2012-06-05].

Part XIX - Tomato, Vegetable and vegetable product. 2007. [Online] Available from: http://www.gov.mu/portal/goc/moh/file/fpart19.doc [Downloaded 2012-0605].

PART XVI - EDIBLE OIL OR FAT.doc [Online] Available from: http://www.gov.mu/portal/goc/ moh/file/fpart16.doc [Downloaded 2012-06-05].

PART XXI - MILK AND MILK PRODUCT.DOC [Online] Available from: http://www.gov.mu/portal/goc/moh/file/fpart21.doc [Downloaded 2012-06-05].

PART XXIII -- MEAT AND MEAT PRODUCT.doc [Online] Available from: http://www.gov.mu/ portal/goc/moh/file/fpart23.doc [Downloaded 2012-06-05].

Part XXVII, Alcoholic beverages [online] available from: http://www.gov.mu/portal/goc/ moh/file/fpart27.doc [Downloaded 2012-05-06].

The Mauritius cane industry authority Act No. 40 of 2011. [Online] Available from: http://faolex .fao.org/docs/pdf/mat116806.pdf. [Downloaded 2012-06-05].

WTO Trade policy Review 2006. Mauritius.

WTO Trade policy Review/176. 2 November 2001

WTO Trade policy Review/176. 2 November 2001

WTO Trade policy Review/176. 2 November 2002

WTO Trade policy Review/S/222. 18 September 1995. Trade Policy Review Mauritius Report by the Secretariat.

\section{Mozambique}

Sebei, E. 2007. Trade potentials between South Africa and Mozambique. p 1-52. [on-line] Available from http://www.nda.agric.za/docs/researchP/MozambiStudy.pdf [Downloaded 21-05-2012].

Mozambique Decree No. 56/1998 of 11 November 1998

Decree No. 52/1998 of 29 September 1998, as amended by Decree No. 37/2002 of 11 December 2002 
WTO Trade Policy Review 2001 - 2011

Rial, D.P. 2014. Study of average Effects of Non-Tariff Measures on Trade Imports: Policy Issues in International Trade and Commodities. Research Study Series No 66

\section{Namibia}

Agricultural Pest Act 1973. Available at: http://www.environment-namibia.net/tl_ files/pdf_documents/legal/acts/ACT_1973-04_\%2303_Agricultural\%20Pests\%20Act.pdf (Accessed: 16 April 2016).

Agronomic Industry Act N. 20 of $1992 . \quad$ Available at: http://www.commonlii.org/na/legis/num_act/aia1992229.pdf (Accessed: 16 April 2016).

Animal diseases and Parasites Act of 1956. http://www.environment-namibia.net/tl files/pdf_documents/legal/acts/ACT_2005-

09\%20\%2310\%20Animal\%20Diseases\%20and\%20Practises\%20Amendment\%20Act.pdf (Accessed: 16 April 2016).

Customs and Excise Act No. 20 of 1998. Available at: http://www.osall.org.za/docs/2011/ 03/Namibia_Customs_and_Excise_Act_1998.pdf (Accessed: 16 April 2016).

Draper, P. \& Khumalo, N (eds). 2007. Trade in Genetically Modified Foods. Johannesburg, South Africa: The SouthAfrican Intitute of International Affairs.

Gillson, I. \& Charalambides, N. 2011. Addressing Non-Tariff Barriers on Regional Trade in Southern Africa.

Anon. Namibia Country Report, 2003. Available at: http://www.sadctrade.org/files/TPR \%20Namibia.pdf (Accessed: 16 April 2016).

Agricultural Product Standards Act, 119 of 1990 . Available at: http://www.nda.agric.za/doaDev/sideMenu/foodSafety/doc/Act\%20119.pdf (Accessed: 16 April 2016).

Meat Industry Act, 1981. Available at: http://www.nammic.com.na/index.php/library/send/50-meat-industry/24meat-industry-act-12-of-1981 (Accessed: 16 April 2016).

Foodstuff, Cosmetics and Dinfecants Amendment Act No 39 of 2007. Available at: http://faolex.fao.org/docs/pdf/saf85626.pdf (Accessed: 16 April 2016).

Customs and Excise Act No. 20 of 1998. Available at: http://www.osall.org.za/docs/2011/03/ Namibia_Customs and_Excise_Act 1998.pdf (Accessed: 16 April 2016),

Sirongo, K.S. 2007. Trade Policy Review: Namibia. Stellenbosch: Tralac.

\section{South Africa}

Animal Health Act No 7 of 2002. Available at: http://faolex.fao.org/docs/pdf/saf37562.pdf.

Animal Protection Act No 71 of 1962. Available at: http://www.rattyrascals.co.za/animalprotectionact.html.

Meat Safety Act No 40 of 2000. Available at: http://www.nda.agric.za/doaDev/sideMenu /APIS/doc/MEATSAFETY.pdf.

Foodstuff, Cosmetics and Disinfectants Amendment Act No 39 of 2007. Available at: https://www.capetown.gov.za/en/CityHealth/Documents/Legislation/Act\%20-

\%20Foodstuffs, \%20Cosmetics\%20and\%20Disinfectants\%20Amendment\%20Act\%20-

\%2039\%20of\%202007.pdf.

Impact of the Consumer protection Act of 2009, on the Food Industry.

Agricultural Product Standards Act, 119 of 1990. Available at: http://www.nda.agric.za/doaDev/sideMenu/foodSafety/doc/Act\%20119.pdf.

ABATTOIR HYGIENE Act No121 of 1992. Available at: http://www.kzndard.gov.za/Portals/ 0/Environment/EIA/ACTS/Abattoir\%20Hygiene\%20Act.pdf.

Agricultural Pests Act No 36 of 1983. Available at: http://www.nda.agric.za/doaDev/sideMenu/plantHealth/ docs/The\%20Agricultural\%20Pests\%20Act,\%201983\%20(Act\%20No.36\%20of\%201983).pdf.

Regulations relating to grading, packaging and marking of canned mushroom intended for sale in the Republic of South Africa: Amendment 2010.

Perishable Products Export Act No 9 of 1983. Available at: http://www.gov.za/sites/www.gov.za/ files/Act\%209\%20of\%201983.pdf.

GMO Act No 15 of 1997. Available at: http://us-cdn.creamermedia.co.za/assets/articles/attachments/03158 genmodorgact15.pdf.

Liquor Product Act No 60 of 1989. Available at: http://www.sawis.co.za/winelaw/download/Regulations annotated 07 2012.pdf.

Gillson, I. \& Charalambides, N. 2011. Addressing Non-Tariff Barriers on Regional Trade in Southern Africa. Imani Development International Ltd, 2007. 2007 Update survey of non-tariff barriers to trade: Lesotho.

Wine and Spirit Control Act No 47 of 1970. Available at; http://www.gov.za/sites/www.gov.za/files/a2598.pdf. 


\section{Swaziland}

Animal Disease Act No. 7 of 1965.

Customs and Excise Act, 1964.

Import Control Order, 1976.

Import levy on agricultural products, 2009.

Levy on milk and dairy products, 2009

Liquor Act, 1964.

National Agricultural Marketing Board Act, 1985; Legal Notice No. 2, 2000. Sales Tax Act, 1983.

Standards and Quality Control Act, 2001.

Standards and Quality Control Act, 2001..

The Agriculture Act of 1967 (Part XII).

\section{Zambia}

Dairies industry Development Act No. 22 of 2010. Available at: http://www.ilo.org/dyn/natlex/docs/ELECTRONIC/86264/97233/F1021916789/ZMB86264.pdf.

Dairy Product Marketing and Levy Act 1964. Available at:

http://www.parliament.gov.zm/sites/default/files/documents/acts/Dairy\%20Produce\%20Marketing\%20and\%20

Levy\%20Act.pdf.

Department of International Development. 2002. Assessment of trends in the Zambian agriculture sector.

Food and Agricultural organisation. 2005. Analysis of the food situation in Zambia. FAO/WHO conference on food safety for Africa, Harare, Zimbabwe, 3-6 October 2005.

IMANI Development International Ltd. 2007 update Survey of Non-Tariff Barriers to Trade Zambia.

Pig Industry Act of 1964. Available at: http://www.zamlii.org/zm/legislation/consolidated-act/251.

Plant Pest and Disease (Importation) Regulation 1996. Available at: http://zambialaws.com/SubsidiaryLegislation/chapter-233-plant-pests-and-diseases-act-subsidiary-legislation.html\#PLANTＰESTS AND DISEASES (IMPORTATION) REGULATIONS.

Plant Pest and Disease Act of 1959. Available at: http://www.zamlii.org/zm/legislation/consolidated-act/233.

Tobacco Act of 1967. Available at: http://www.zamlii.org/zm/legislation/consolidated-act/237.

United States Agency International Development (USAID) 2011. Legal Institutional Reform in Zambia's Agricultural Sector.

World Bank \& USAID. 2006. Zambia: SPS Management. Recommendations of joint World Bank/USAID Assessment Team.

\section{Tanzania}

Abegaz, M. nd. Mobilizing aid for trade for SPS-related technical cooperation in East Africa. SPS balance sheet for Tanzania. (WTO, 28 January 2000).

Africa Region Working Paper Series No. 42. 2002. Tanzania’s Cotton Sector: Constraints and Challenges in a Global Environment.

Belino, E.D. 1992. Organisation of veterinary public health in Africa. Rev. sci. tech. Off. Int. Epiz., 11 (1):99116.

East African Community (EAC). 2010. Catalogue of East African Community Standards.

FAO/WHO. 2005. Effective food control system: Practical approaches for the African region. Development of a National strategy for food control, the experiment of Tanzania.

Parliament of Tanzania. 1968. Liquor Act of 1968.

Tanzania Food and Drug Authority. 2009. Guidelines for application for registration of pre-packed food in Tanzania. Report No. 2.

The United Republic of Tanzania Ministry of Health and Social Welfare Tanzania Food and Drug Authority. 2006. Guidelines for importation and exportation of food.

United Nation Conference on Trade and Development. 2005. Cost of the Agri-food safety and SPS compliance: United Republic of Tanzania, Mozambique and Geneva: Tropical fruits.

\section{Zimbabwe}

Export Processing Zones Act [Chapter 14:07]. 2002. Available at: http://www.parlzim.gov.zw/acts-list/exportprocessing-zones-act-14-07 (Accessed: 16 April 2016).

Fertilizers, Farm Feeds and Remedies Act [Chapter 18:12]. 2001. Available at: http://faolex.fao.org/docs/pdf/zim24974.pdf (Accessed: 16 April 2016).

Fruit Marketing Act [Chapter 18:13].2001. Available at: http://faolex.fao.org/docs/pdf/zim26296.pdf (Accessed: 16 April 2016). 
Grain Marketing Act [Chapter 18:14]. 1979. Available at: http://faolex.fao.org/docs/pdf/zim60693.pdf (Accessed: 16 April 2016).

Liquor Act [Chapter 14:12]. 2001. Available at: http://www.parlzim.gov.zw/acts-list/liquor-act-14-12 (Accessed: 16 April 2016).

Seeds Act [Chapter 19:13]. 2001. Available at: http://www.wipo.int/wipolex/en/text.jsp?file_id=214681 (Accessed: 16 April 2016).

Sugar Production Control Act [Chapter 18:19]. 1973. Available at: http://faolex.fao.org/docs/pdf/zim26311.pdf (Accessed: 16 April 2016).

Tobacco Industry and Marketing Act [Chapter 18:20]. 2001. Available at: file:///C:/Users/User/Desktop/TOBACCO_INDUSTRY_AND_MARKETING_ACT_18_20.pdf (Accessed: 16 April 2016).

Trade and Markets Division. 2003. Economic and Social Development Department. WTO agreement on agriculture: The implementation of experience. Available at: http://www.fao.org/publications/card/en/c/914a8b48-e21a-5983-89f0-df8038436a06/ (Accessed: 16 April 2016).

\section{Other Institutions}

COMESA Secretariat Document

FAO policy documents

IFAD Documents

ITC Official Data

SACU Secretariat Documents on Industrial Policy

SADC Secretariat Documents

UNCTAD TRAINS Database

World Bank Documents

World Economic Forum (2014) The Global Enabling Trade Reports. Geneva

World Trade Organisation Integrated Trade Intelligence portal (I-TIP)

World Integrated Trade Solutions (WITS)

World Trade Organisation, Trade Monitoring Database

World Trade Organisation, WTO Trade Policy Reviews 1998 - 20012 